\title{
WYRAŻANIE SPRZECIWU POPRZEZ DUCHOWOŚĆ. PRZYPADEK MINIMALIZMU
}

Andrzej Kasperek
Uniwersytet Śląski

Kontrkulturowy ruch hipisowski można potraktować jako kolejną ekspresję pojawiającej się co pewien czas tendencji kulturowej, w której odradza się pragnienie uwolnienia od posiadania rzeczy, powrót do natury oraz do ideału prostego życia. W artykule kwestia cyklicznego odradzania się takiej tendencji kulturowej zostanie podjęta na przykładzie współczesnego zjawiska określanego mianem minimalizmu. W wielu punktach minimalizm nawiązuje do kontrkulturowych postulatów, choć są i punkty, w których różni się od hipisowskiej kontestacji. Minimalizm stanowi alternatywę dla masowej konsumpcji współczesnych społeczeństw, wpisuje się zarazem w długą historię - której ruch hipisowski jest także ogniwem - indywidualnej oraz zbiorowej kontestacji pragnienia posiadania rzeczy oraz krytyki materialistycznej orientacji życiowej.

Minimalizm uznać więc należy za część tej długiej tradycji, na która składaja się idee głoszone przez filozofów (np. Sokratesa, cyników czy stoików), założycieli wielkich religii (np. Buddę czy Jezusa), anonimowych wyznawców średniowiecznych ruchów ubogich (beginów, begardów czy Braci Apostolskich), reprezentantów XIX-wiecznego romantyzmu (np. amerykańskich transcendentalistów takich jak Henry David Thoreau), kontrkultury XX-wiecznej czy w końcu protagonistów XX-wiecznego ruchu dobrowolnej prostoty. Ten sprzeciw, co pokazuje historia, zawsze przesycony był pewną formą duchowości, choć, co także wypada zaznaczyć, nie zawsze przyjmowal formy charakterystyczne dla życia religijnego. Pojęcie „duchowość”, które w ostatnich dwóch dekadach zaczęło przyciagać uwagę socjologów badających życie religijne, wymaga oczywiście każdorazowo doprecyzowania. Na potrzeby poniższych rozważań warto przyjąć, że przykłady odrzucenia pragnienia posiadania łączy ten typ duchowości, w którym za Markiem Jeżowskim można dostrzec dążenie 
do osiagnięcia doskonałości (2010: 76-77). Bez wattpienia takie dążenie spotykamy także w minimalizmie.

Wspomnianą przed chwilą tendencję kulturową, polegającą na głoszeniu ideału życia ascetycznego (odrzucenie luksu) oraz pochwale prostoty, potraktować można jako tendencję par excellence kontrkulturową. Konsekwencją takiego rozumienia będzie jednak reinterpretacja samego pojęcia „kontrkultura”. Warto w tym miejscu odwołać się do dwóch sposobów konceptualizacji problematyki kontrkulturowej, by następnie, dokonując syntezy tych stanowisk, zaproponować przyjęte na potrzeby niniejszego artykułu rozumienie pojęcia kontrkultury.

Pierwszy sposób ujmowania problematyki kontrkultury wiąże się z tym, co Peter Meyer w swojej Historii sz̨tuki europejskiej określił mianem „potrzeby romantycznej”: potrzeby, której istnienie ma charakter uniwersalny, choć każdorazowo manifestuje się ona w odmiennej szacie historycznej ${ }^{1}$.

Prąd romantyczny jest zawsze ruchem, który się przeciwstawia panującej „nowoczesności”. Skoro tylko wytworzy się gdzieś wysoka kultura miejska lub dworska, można tam dostrzec ruchy romantyczne, reprezentowane nie przez jakaśs rewolucyjna partię opozycyjna, ale przez samych przedstawicieli tej wysokiej kultury. Oznacza ona bowiem zawsze specjalizację w określonym kierunku i odsunięcie od tego, co podstawowe i ludzkie. Ta właśnie strata w zakresie skali, rozległości przeżyć ma być wyrównana, przynajmniej symbolicznie, przez romantyczne wyobrażenia. Członkowie przodującej warstwy społecznej odczuwają czasami swe wysoce wystylizowane życie jako ciężar i tęsknią za tym, co proste, niewymuszone i naturalne (Meyer 1973: 223).

Jak pisze dalej Meyer, „człowiek nastrojony romantycznie” próbuje wyrwać się z ograniczeń „przymusu zawodowego i społecznego” i poszukuje „prostoty graniczącej z prymitywizmem” (tamże: 224). Peter Meyer przypisuje uniwersalne znaczenie kategorii nowoczesności, podobnie jak potrzebie romantycznej, nie ograniczając ich dialektyki do czasów nam najnowszych. Powiedzieć można: każda epoka ma swoją nowoczesność, polegająca na specjalizacji kultury wysokiej, specjalizacji związanej z alienacja od tego, co ludzkie, wręcz swoistą dehumanizacją, i w imię tego, co najbardziej ludzkie, a zarazem esencjonalne (podstawowe), występuja rzecznicy prostoty, realizujący potrzebę romantyczna. A zatem, rozwijając

$1 \mathrm{Na}$ temat związków między potrzebą romantyczną a kontrkulturą zob. Kasperek 2013: $35-37$. 
koncepcję potrzeby romantycznej, zauważyć można, że każdorazowe ukonstytuowanie się wysokiej kultury (miejskiej bądź dworskiej) prowadzi do wytworzenia się wobec niej kontrkultury.

Maria Janion i Maria Żmigrodzka w ciekawy sposób interpretują koncepcje potrzeby romantycznej Meyera, nadając jej socjologiczny sznyt. Pisząc o „socjologii postawy romantycznej” badaczki zauważaja, że mający swoje początki w XVIII stuleciu, a w XIX uzyskujący swoją dojrzałość romantyzm, jako bunt przeciwko kulturze dominującej, miał charakter kontrkulturowy.

Kiedy spojrzymy na bunt romantyków przeciwko kulturze, to zauważymy, że [...] romantycy usiłuja stworzyć nową kulturę, posługując się kontrkulturami. Tworzą właściwie kontrkulturę przeciwko kulturze panującej, tworzą nową kulturę $z$ kontrkultur, to znaczy czerpią $z$ tych wszystkich kultur, które ich zdaniem nie znalazły odpowiedniego miejsca w kulturze panującej (Janion, Żmigrodzka 2004: 191).

Ostatnie zdanie z powyższego cytatu wydaje się szczególnie ważne, kieruje bowiem uwagę w stronę tego, co za Colinem Campbellem określić można mianem kulturowego undergroundu społeczeństwa ${ }^{2}$, na który składają się wszystkie dewiacyjne systemy wierzeń i praktyk (1972: 122), a zatem te wątki kulturowe (duchowość zawsze przybiera pewne formy kulturowe), które zostały zepchnięte poza mainstream dominującego porządku kulturowego. Chodzi tutaj o heterodoksalne nurty religijne, duchowe czy w końcu magiczne, o to, co mieści się w szeroko rozumianych „,podziemnych”, nieortodoksyjnych nurtach kultury. Pomimo wielkiego zróżnicowania elementów tworzących kulturowy underground istnieja przesłanki, by traktować to podziemie kulturowe jako całość. Przede wszystkim wspomniane aktywności łączy ich heterodoksyjność, a zarazem dewiacyjność w relacji do dominującej i ortodoksyjnej kultury. Problematykę duchowego wymiaru kontrkultury ująć można także w sposób zaproponowany przez Gillesa Quispela, który pisze o trzech filarach kultury europejskiej: wierze, rozumie oraz gnozie (2008: 143). Ten ostatni filar, gnostycki komponent kultury, stanowi - jak pisze holenderski badacz zachodniej tradycji ezoterycznej Wouter Hanegraaff - tradycyjna zachodnią kontrkulturę (1998a: $373)^{3}$. Rozumienie gnozy ma w tym przypadku charakter typologiczny,

\footnotetext{
${ }^{2} \mathrm{Na}$ ten temat piszę w książce: Wolność spod żnaku undergroundu (Kasperek 2012).

3 Co prawda termin ,kontrkultura” Hanegraaff bierze w cudzysłów, ale cudzysłów ten nie zmienia raczej zaproponowanego powyżej sposobu interpretacji undergroundu oraz gnozy w kategoriach kontrkultury.
} 
a nie chronologiczny, i zakłada przeciwstawienie racjonalnemu sposobowi poznawania rzeczywistości (rozum) oraz objawieniu zewnętrznej rzeczywistości (wiara) przekonania, że prawda może zostać odkryta wyłącznie na drodze wewnętrznego objawienia (gnoza).

Odwołując się więc z jednej strony do Meyera koncepcji potrzeby romantycznej, w której akcentuje się estetyczny wymiar kontrkulturowego przewartościowania, a zarazem podkreśla się znaczenie powrotu do natury oraz głosi apoteozę prostoty, a z drugiej strony sięgając do rozumienia kontrkultury jako poszukiwania wewnętrznego objawienia, w którym podkreśla się duchowy wymiar kontrkultury, warto zaproponować analizę minimalizmu w kategoriach kontrkulturowych (w powyżej rozumianym znaczeniu). Z jednej strony zostanie więc wyeksponowany motywowany potrzebą romantyczną minimalistyczny zwrot w stronę prostoty, z drugiej - duchowy wymiar tego zwrotu, który będzie zaprezentowany z perspektywy socjologii duchowości.

Minimalizm, stanowiący przedmiot niniejszego studium, wiąże się z popularyzowanym głównie poprzez internetowe blogi stylem życia, opierającym się na zasadzie „less is more”. Tak rozumiany minimalizm różni się od jego wcześniejszych artystycznych realizacji, mających miejsce na gruncie malarstwa, rzeźby, muzyki, literatury czy architektury. Zjawisko to wyprowadzone z rejonów artystycznego uniwersum, upowszechniane dzięki współczesnym środkom masowego przekazu, wkracza w obszar życia codziennego.

Minimalizm współczesny ma oczywiście swoich protoplastów we wspomnianej wcześniej tradycji, w której akcentowano znaczenie życia prostego, jednak to, co każe nań spojrzeć jako na z ducha współczesne zjawisko, to fakt, że w znacznej mierze utracił on elitarny charakter, a zarazem stanowi przykład współczesnej recepcji tradycji pochwały życia prostego w czasach sekularyzacji. Te dwa czynniki każą spojrzeć na współczesny minimalizm w perspektywie ciąłości oraz zmiany idei tworzących pewną tradycję kulturową, a zarazem tradycję duchową. Współczesny minimalizm tak przez jego protagonistów, jak i przez osoby z nim bliżej niezwiązane, aczkolwiek posiadające pewne wyobrażenie na jego temat, jest najczęściej wiązany głównie z ograniczaniem do minimum konsumpcji oraz z pozbyciem się nadmiaru rzeczy. To jednak bardzo niepełny i uproszczony obraz, przynajmniej jeśli chodzi o definiowanie minimalizmu przez jego najważniejszych rzeczników, których rozumienie tego zjawiska zbiega się z koncepcja potrzeby romantycznej Petera Meyera. Kiedy autor Historii sztuki europejskiej pisał o „kostnieniu” kultury wysokiej, odsuwającej na bok to, „co podstawowe i ludzkie”, to ten „humanistyczny” i „egzystencjalny” 
wymiar odnajdował właśnie w ekspresji potrzeby romantycznej. Także minimalizm jest przez jego najważniejsze ikony definiowany jako dążenie w życiu do tego, co istotne, podstawowe, najważniejsze, fundamentalne. Taką definicję można znaleźć na przykład w twórczości najsłynniejszego blogera-minimalisty Leo Babauty, który w jednej ze swoich książek, będących de facto drukowana wersja prowadzonego przezeń bloga ${ }^{4}$, cytuje Lin Yutanga twierdzącego, że „mądrość życia polega na eliminacji zbędnych rzeczy" (Babauta 2011: 36). W innej swojej ksiazzce Babauta definiuje minimalizm jako wybór w życiu tego, co istotne, jako umiejętność odrzucania rzeczy nieważnych (2009: VIII-IX, 5-6, passim). W taki sam sposób minimalizm definiuja inni popularni blogerzy-minimaliści: Joshua Becker (2013a), także cytujący Lin Yutanga, Joshua Fields Millburn oraz Ryan Nicodemus (2011: 4, 8-9, 23, passim) ${ }^{5}$ czy Kimberly Wilson (2012: 4). Lejtmotywem twórczości minimalistów jest uproszczenie życia, dążenie do prostoty, dzięki której odsłania się w życiu to, co istotne. Akcentując te dwa dążenia: do tego, co podstawowe, oraz do prostoty, minimaliści daja wyraz istnieniu ni mniej, ni więcej, tylko opisywanej przez Petera Meyera potrzeby romantycznej.

Dwa źródła inspiracji wydają się tutaj odgrywać szczególną rolę, stając się czymś w rodzaju bezpośrednich inspiracji: kontrkultura młodzieżowa lat 60. i 70. ubiegłego wieku oraz ruch dobrowolnej prostoty. Jeśli chodzi o kontrkulturę, to Aldona Jawłowska w swoim klasycznym studium poświęconym młodzieżowej kontestacji pisała nie tylko o hipisowskim powrocie do natury, do tego, co pierwotne, ale i o ich odkrywaniu ,uroku rzeczy prostych” (1975: 150). Minimalizm, choć pozornie odległy od kontrkulturowej kontestacji, w rzeczywistości nigdy by nie zaistniał, gdyby nie ona, podobnie rzecz ma się z ruchem dobrowolnej prostoty, którego związki z minimalizmem są tak ścisłe, że w wielu przypadkach zaliczenie kogoś do pierwszego bądź drugiego zależy nie tyle od prezentowanych poglądów, ile od arbitralnej decyzji samego zainteresowanego, preferującego raczej jedną niż drugą afiliację. Protagoniści ruchu dobrowolnej prostoty (voluntary simplicity movement), powstałego w późnych latach 80. i wczesnych 90. ubiegłego wieku w Stanach Zjednoczonych, podobnie

\footnotetext{
${ }^{4}$ W miarę możliwości będę odwoływać się dalej do takich właśnie książkowych wersji twórczości blogerskiej minimalistów.

5 Najpopularniejszy minimalistyczny blog Zen Habits prowadzony przez Leo Babautę ma miesięcznie milion czytelników i należy do pięciu najpopularniejszych na świecie (jak podaje sam autor), Becoming Minimalist prowadzony przez pastora Joshuę Backera ma ponad 300 tysięcy czytelników miesięcznie, a The Minimalist.com, prowadzony przez Joshuę Fieldsa Millburna oraz Ryana Nicodemusa - ponad 100 tysięcy czytelników miesięcznie.
} 
jak późniejsi minimaliści, głoszą pochwałę antykonsumpcjonistycznego stylu życia, przy czym minimalizm można uznać za rodzaj mutacji tego ruchu, będący de facto popkulturową i nieco zwulgaryzowaną (co ma bez watpienia pewien związek $z$ charakterem blogosfery) reinterpretacja ruchu dobrowolnej prostoty. Mary Grigsby, charakteryzując ruch dobrowolnej prostoty, choć zwraca uwagę na istnienie w jego ramach pewnych form instytucjonalnych (np. simplicity circles), optuje za tym, by w jego przypadku nie stosować pojęcia ruchu społecznego, lecz ruchu kulturowego, skierowanego przeciw dominującej kulturze (kulturze konsumpcyjnej), ruchu „luźno związanego" (2004: 9). Jeszcze luźniejszą formę przyjmuje minimalizm, w przypadku którego trudno mówić o istnieniu jakichś trwałych form zinstytucjonalizowanego życia. Tym, co łączy ruch dobrowolnej wspólnoty i minimalizm, jest bez wątpienia wspólnota postmaterialistycznych wartości, akcentowanie samorozwoju, autentyczności czy autoekspresji, a zatem trudno i tutaj nie zauważyć kontynuacji kontrkulturowej aksjologii. Jak pisał Amitai Etzioni, powstanie ruchu dobrowolnej prostoty w społeczeństwach późnego kapitalizmu daje się wyjaśnić na gruncie psychologicznej teorii Abrahama Maslowa. Hierarchię potrzeb Maslowa wieńczy autoekspresja, a zatem, jak twierdzi Etzioni, ruch dobrowolnej prostoty wydaje się dobrym przykładem zaspokajania potrzeby autoekspresji (2004: 415). Akcentowanie rosnącego znaczenia autoekspresji w społeczeństwach postmaterialistycznych stanowi rdzeń koncepcji Ronalda Ingleharta, koncepcji będącej de facto socjologiczną interpretacją teorii Maslowa. Potraktowanie ruchu dobrowolnej prostoty oraz minimalizmu jako manifestacji wartości charakterystycznych dla społeczeństw postmaterialistycznych idzie w poprzek dominującemu przekonaniu, że wzrastający poziom konsumpcji jest jedynym scenariuszem przyszłości dla społeczeństw kapitalistycznych.

Z jednej więc strony rzecznicy prostoty podzielają wartości budujące mainstream kulturowy współczesnych, zaawansowanych cywilizacyjnie społeczeństw, ogniskujących się wokół triady pojęć: indywidualizm-autonomia-autoekspresja (Inglehart i Welzel 2007: 137), z drugiej - reprezentuja kontrkulturowe par excellence dążenie do zakwestionowania kulturowego imperatywu konsumowania i gromadzenia, w to miejsce proponując zwrot w stronę życia prostego. Jeden z najpopularniejszych blogerów-minimalistów Joshua Becker pisze, że współczesna kultura narzuca nam coraz szybsze życie, coraz cięższą pracę oraz konformistyczne zachowania. Wskutek tego człowiek współczesny gubi niepowtarzalność, pasje, traci okazję, by znaleźć to, dzięki czemu mógłby osiagnąć spełnienie. Jako remedium Becker proponuje, by „żyć kontrkulturowym życiem”, które polega na uzmysłowieniu sobie, że posiadanie nie daje szczęścia ani poczucia 
bezpieczeństwa, popularność - satysfakcji, a seks - miłości. Realizacja postulatu kontrkulturowego życia zakłada kilka kroków polegających między innymi na ograniczeniu dostępu do mediów, poszukiwaniu wewnętrznego spokoju, ograniczeniu płynącego zewsząd hałasu. Trzeba, pisze będący pastorem Becker, zaczać słuchać swojego wewnętrznego głosu, np. poprzez medytację, oraz podążać za nowoodkrytymi pasjami (2013b). Kontrkulturowość wedle rozumienia Beckera polegać miałaby zatem na zwrocie w subiektywną stronę, na odkrywaniu własnego wnętrza, głębokiej jaźni, trudno więc nie zauważyć tutaj podobieństwa do głoszonej przez Charlesa Taylora tezy o „radykalnym zwrocie nowoczesnej kultury w stronę subiektywizmu" (the massive subjective turn of modern culture) (Taylor 1991: 21, Taylor 1996: 28). Jeśli inni minimaliści radza, by słuchać swojego wewnętrznego głosu (Babauta 2008: 29, Millburn i Nicodemus 2011: 69, Wilson 2013: 23), by być sobą (Strobel 2012: 5), by zajmować się sobą oraz troszczyć o jak najlepsze poznanie swojej duszy, a nie o gromadzenie rzeczy (Loreau 2008: 177, 239), to w tego typu dyskursie spotykamy się nie tylko z kulturowa tendencja, ale i z propozycja pielęgnowania pewnego typu duchowości, który określić można mianem duchowości wewnętrznego spokoju. Taylora tezę o radykalnym zwrocie kultury w stronę subiektywizmu na grunt rozważań poświęconych duchowości przenieśli Paul Heelas, Linda Woodhead oraz współpracownicy, którzy w głośnej książce noszącej wymowny tytuł The Spiritual Revolution. Why Religion Is Giving Way to Spirituality sformułowali tezę subiektywizacyjną mówiąca, że „«radykalny zwrot nowoczesnej kultury w stronę subiektywizmu» faworyzuje i wzmacnia te formy duchowości (życie-subiektywne), które zapewniają subiektywnościom wyjątkowość i traktuja je jako główne źródło znaczenia, a osłabia te formy religii (życie-jako), które tego nie czynią" (2007: 78).

Tezy stawiane przez Taylora, Heelasa i Woodhead (wraz ze współpracownikami) koresponduja z koncepcją społeczeństwa postmaterialistycznego Ingleharta, który razem z Christianem Welzelem pisał, że w fazie industrialnej znaczenie religii maleje, w fazie postindustrialnej słabnące znaczenie organizacji religijnych utrzymuje się, zarazem jednak życie duchowe przekształca się $\mathrm{w}$ formy kompatybilne $\mathrm{z}$ self-expression values, czyli z wartościami charakteryzującymi postmaterialistyczną orientację zachodnich społeczeństw (Inglehart, Welzel 2007: 22). Wartości charakterystyczne dla społeczeństw postmaterialistycznych, takie jak autonomia, autentyczność, autoekspresja, poszukiwanie szczęścia, samodoskonalenie się czy samorealizacja, stały się zarazem tematami charakterystycznymi dla tzw. nowej duchowości. Thomas Luckmann już w latach 60. ubiegłego wieku, gdy tworzył swoją koncepcję niewidzialnej religii, zwracał uwage 
na pojawienie się w tym czasie nowych tematów religijnych: autonomia, samoekspresja ${ }^{6}$ czy samorealizacja (1996: 145-152). Nie przez przypadek także zarówno Luckmann, jak i Inglehart zwracają szczególną uwagę na kwestię upowszechnienia się w latach 60. ubiegłego wieku swoistego imperatywu autoekspresji, akcentując tym samym doniosłość dziedzictwa kontrkultury młodzieżowej.

Warto teraz powrócić do wspomnianej na początku artykułu możliwości definiowania duchowości w kategoriach doskonalenia się. Marek Jeżowski, odwołując się do rozumienia duchowości przez Władysława Tatarkiewicza, pisze: ,Jeżeli [...] w istniejących definicjach duchowości (transgresji, transcendowaniu) nadamy celowy charakter ludzkiego działania, zamieniając ją na «doskonalenie», okaże się, że duchowość (zarówno religijna, jak i niereligijna) to ogólnie rzecz biorąc, dążenie do doskonałości ze względu na wartości wyższe, albo jeszcze krócej: głęboko umotywowane dążenie do doskonałości moralnej [...]" (Jeżowski 2010: 76-77). Choć definicja zaproponowana przez Jeżowskiego oraz wypływający z niej wniosek, że konsekwencją takiego rozumienia duchowości jest zajmowanie się nią nie w ramach socjologii religii, ale raczej w ramach socjologii moralności, jest dyskusyjna, to akurat jeśli chodzi o prezentowana przez minimalistów duchowość wewnętrznego spokoju (resp. duchowość prostoty), rozumienie duchowości jako samodoskonalenia okazuje się całkiem owocne, wyeksponowany bowiem zostaje w tym przypadku ascetyczny wymiar duchowości tego typu. Jak pisał Giuseppe Giordan, oryginalne znaczenie pojęcia ascetyzmu odsyła do metodycznego ćwiczenia fizycznego, intelektualnego oraz moralnego prowadzącego do samodoskonalenia (2009: 227). Co jednak ważne, Giordan wpisuje problematykę ascezy w szerszą perspektywę relacji ciała do ducha, a zarazem dodaje, że jeszcze do niedawna to religia definiowała tę relację, dzisiaj natomiast - właśnie duchowość. W perspektywie współczesnej duchowości relacja ciało - duch zostaje zsekularyzowana, a samo dążenie do doskonałości może dokonywać się - jak pisał Jeżowski - „ze względu na wartości wyższe”, przy czym nie muszą one wiązać się z „klasycznym” rozumieniem sacrum, zawiadywanym, by się tak wyrazić, przez instytucje życia religijnego.

Należy jednocześnie podkreślić, że duchowości wewnętrznego spokoju nie powinno się sprowadzać do duchowości określanej bardzo nieprecyzyjnym terminem New Age. Jeśli chodzi o ten drugi typ duchowości, to trudno określać ją mianem ascetycznej, a zarazem wielu badaczy zwraca

${ }^{6}$ Podaję za tłumaczeniem tego terminu w książce Luckmanna jako samoekspresja, a nie autoekspresja. 
uwage na jej konsumpcyjny charakter (Bruce 2000: 232, Bruce 2006: 45, York 2001: 367, Possamai 2005: 49, Campbell 2005). Wpisuje się ona natomiast w duchową tendencję, którą Charles Taylor określa mianem transcendentalnego rozwoju (flourishing) i przeciwstawia ekskluzywnemu (i świeckie$\mathrm{mu}$ ) humanizmowi (Taylor 2007: 618-639). O ile drugi pozbawiony jest transcendentnego odniesienia i może prowadzić do immanentnej i niereligijnej duchowości bądź uniwersalizacji moralnych kodów, zainteresowania problematyką ubóstwa (Mouzelis 2012: 84), o tyle w przypadku pierwszego horyzontem odniesienia pozostaje transcendentny Bóg (np. chrześcijański). Ekskluzywny humanizm jest świecki, choć może prowadzić do „immanentnego rozwoju", to jednocześnie zrywa relacje człowieka z kosmosem i tajemnicami ludzkiej egzystencji - dlatego też New Age umieścić należy raczej $\mathrm{w}$ ramach transcendentalnego rozwoju, mimo że zawiera on bez watpienia także cechy charakterystyczne dla ekskluzywnego humanizmu. Jeśli chodzi natomiast o duchowość minimalistów, to sądzić można, że nie mieści się ani w pierwszym, ani w drugim typie, co nie znaczy jednak, że niemożliwa jest jej analiza jako formy duchowości. Warto wykorzystać w tym miejscu sugestię Nicosa Mouzelisa, by do typologii Taylora dodać jeszcze jeden typ odnoszący się do pojęcia ,indwelling God” (Mouzelis 2012: 85). Typ ten unika immanentnej redukcji ekskluzywnego humanizmu, a zarazem pozwala na poszukiwania duchowe poza duchowością religijną. Jak pisze Mouzelis, ten trzeci typ, leżący pomiędzy tym, co świeckie, a tym, co święte, stanowi przykład apofatycznej duchowości, w której duchowy poszukiwacz staje się „pustym naczyniem”, które - odrzucając w medytacji wszelkie myśli, w tym także wiarę w istnienie boskiej siły - odrzuca jakiekolwiek systemy wierzeń (w przypadku duchowości New Age mamy do czynienia z duchowością katafatyczna). Znika tutaj podział na podmiot i przedmiot, sacrum i profanum, zatarciu ulega myślenie oparte na binarnych opozycjach. Pozostaje - pisze Mouzelis - bezgraniczne współodczuwanie z jaźnią, z innymi i naturą. To typ duchowości bliskiej buddyzmowi zen. I tutaj właśnie dotykamy sedna duchowości wewnętrznego spokoju spod znaku minimalizmu (ale i szerzej: protagonistów prostoty).

Związki minimalizmu z buddyzmem zen wydają się najbardziej wyraźne w przypadku twórczości Leo Babauty oraz Dominique Loreau. Ten pierwszy prowadzi blog noszaccy tytuł Zen Habits, ta druga jest zafascynowana buddyzmem zen, mieszka w Japonii i ma za sobą doświadczenie pobytu w klasztorze zen. W przypadku Babauty, który lubi cytować buddyjskich mędrców (nie tylko zen zreszta), odwołania do tego odłamu buddyzmu są mniej bezpośrednie, a sam termin „zen”, występujący w tytule jego bloga, należałoby raczej tłumaczyć jako praktyki przynoszące wewnętrzny 
spokój. Warto pamiętać o tym, że w języku angielskim wyrażenie to be zen (analogicznie w języku francuskim être zen) znaczy tyle, co bycie spokojnym, doświadczenie wewnętrznego spokoju. Taka adaptacja samego terminu jest jedna z konsekwencji kontrkulturowej recepcji buddyzmu zen, bardzo popularnego i wpływowego w ruchu hipisów, a wcześniej wśród przedstawicieli beat generation, następnie popularyzacji tej odmiany buddyzmu, czego efektem stało się wykraczanie idei i praktyk z nim związanych z obszarów undergroundu i przenikanie (oczywiście w uproszczonej wersji) do popkultury. Rosnące zainteresowanie buddyzmem zen na Zachodzie datuje się oczywiście wcześniej niż w czasach kontrkulturowej kontestacji, szczególnie ważny wydaje się tutaj okres XIX-wiecznego romantyzmu, do którego w tak wielu punktach nawiązywać będą protagoniści kontrkultury. Opisywani przez Theodore'a Roszaka młodzi buntownicy przypominaja bowiem XIX-wiecznych romantyków w swoim oporze wobec społeczeństwa technokratycznego, opartego na racjonalności, skuteczności i postępie (1973: 56). Co istotne jednak, Roszak definiował kontrkulturę jako zwrot w stronę mistyki, okultyzmu i magii (tamże: 125).

Odwrót od technokratycznego społeczeństwa wiązał się z odkrywaniem z jednej strony zachodniej tradycji ezoterycznej, z drugiej zaś - wschodnich tradycji religijnych (obecnych już, jak wcześniej zostało to wspomniane, u romantyków), słowem: z odkrywaniem idei (i praktyk) undergroundowych, odwołujących się do zakazanego i niszowego doświadczenia - gnozy w rozumienie Quispela. I buddyzm zen odegrał tutaj szczególną rolę, zwłaszcza w Stanach Zjednoczonych, gdzie pierwsza fala kulturowej transmisji buddyzmu wiązała się ze środowiskiem transcendentalistów (Ralph Waldo Emerson, Henry David Thoreau, Walt Whitman) (Cusack 2013). Recepcja buddyzmu zaczęła przekraczać wąskie naukowe i artystyczne środowiska pod koniec XIX wieku, głównie za sprawą Henry'ego Steela Olcotta i Heleny Bławatskiej oraz założonego przez nich w 1875 roku w Nowym Jorku Towarzystwa Teozoficznego, w którym wielką popularnością obok okultyzmu cieszył się także buddyzm (teozofię nazywano wtedy wręcz mianem „buddyzmu ezoterycznego”) (D’Onza Chiodo 2005: 121). Mariangela D’Onza Chiodo zwraca uwagę na odmienną historię buddyzmu w USA w porównaniu z Europa. Specyfika ta była przede wszystkim konsekwencją osiedlania się na terytorium USA wielkiej rzeszy imigrantów z Chin i Japonii, imigrantów chcących zachować rodzime tradycje religijne. W 1893 w Chicago odbył się Światowy Parlament Religii, w czasie którego wykład na temat buddyzmu zen przedstawił Sōen Shaku (mistrz szkoły zen). Shaku nawiązał kontakty z szefem jednego z wydawnictw, który obją patronat nad rozpowszech- 
nianiem buddyzmu w USA. Do współpracy obok Sōena Shaku został zaproszony także Daisetz T. Suzuki (tamże 2005: 126). Cusack podkreśla wpływ, jaki twórczość (także translatorska) Suzukiego wywarła między innymi na Alana Wattsa (którego określić można mianem kontrkulturowego „proroka” buddyzmu zen), Philipa Kapleau, Johna Cage’a, Thomasa Mertona czy poetów okresu beat generation (Jack Kerouac, Allen Ginsberg, Gary Snyder) (Cusack 2013). Warto wspomnieć także o głośnej książce Roberta M. Pirsiga Zen and the Art of Motorcycle Maintenance opublikowanej w $1974 \mathrm{roku}^{7}$. Książka ta bez watpienia stała się inspiracja do powstania szeregu książek będących wariacją na temat zen: Zen and the Art of Running (Larry Shapiro), Zen and the Art of Falling in Love (Brenda Shoshanna), Zen and the Art of Happiness (Chris Prentiss), Zen and the Art of Making a Living (Laurence G. Boldt), i wielu innych.

Babauty czy Loreau poszukiwanie duchowości wewnętrznego spokoju (jak i innych minimalistów, zwłaszcza tych będących Amerykanami, a nie będzie przesadą twierdzenie, że minimalizm najintensywniej rozwija się w USA) wyrasta więc z duchowego dziedzictwa kontrkultury, z jej fascynacji buddyzmem zen, następnie zaanektowanym przez popkulturę, stąd u minimalistów buddyzm ten występuje już w wersji pop. W czasach hipisowskiej kontestacji buddyzm zen z jego postulatem zwrócenia się w stronę własnego wnętrza, poszukiwania wewnętrznego spokoju, ale i upowszechniania opartego na współczuciu (compassion) stosunku do innych ludzi oraz przyrody, stał się synonimem oporu przeciwko dominującemu amerykańskiemu stylowi życia. Zwrot w stronę poszukiwań wewnętrznego spokoju odgrywa tę samą rolę w minimalizmie, przy czym inaczej niż w ruchu hipisowskim (czy szerzej: kontrkulturze młodzieżowej) nie ma on rewolucyjnych aspiracji, by w radykalny sposób zmienić społeczeństwo.

Buddyzm zen, podobnie zresztą jak minimalizm, można rozpatrywać w kontrkulturowych kategoriach. Po pierwsze więc, zgodnie z Meyera definicja potrzeby romantycznej, spotykamy się tutaj ze zwrotem w stronę prostoty, pochwała życia zgodnego z rytmem natury (nie przez przypadek zatem to właśnie w czasach romantyzmu XIX-wiecznego wystapiła pierwsza fala zainteresowania orientalnymi ideami i praktykami), po drugie, z perspektywy zachodniej kultury buddyzm stanowił element undergroundu, gnozy (w typologicznym znaczeniu, które mu nadaje Quispel)

\footnotetext{
7 Philip Harnden w książce Journeys of Simplicity, która stanowi poetycką impresję na temat twórczości protagonistów prostoty (np. Bashō, Henry David Thoreau czy Jezus, ale i postaci fikcyjnych, jak np. ojciec Zossima czy Bilbo Baggins), poświęca fragment postaci Roberta Pirsiga, określając go zresztą jako amerykańskiego buddystę zen (Harnden 2003: 90-93).
} 
opartej na wewnętrznym objawieniu, związanym z duchowymi poszukiwaniami. Zadomowienie się najważniejszych idei charakterystycznych dla zen w popkulturze stępia oczywiście jego kontrkulturowy charakter, jednak nie unieważnia undergroundowego charakteru, który jeszcze do niedawna posiadal. $Z$ podobnym zjawiskiem spotykamy się w przypadku minimalizmu, który jest kontynuacją, a zarazem adaptacją do warunków współczesnych, zsekularyzowanych społeczeństw, obecnych od wieków w kulturze zachodniej elementów składających się na duchowość prostoty. Minimalizm jako „słuchanie swojego wewnętrznego głosu” także ma undergroundowe korzenie, przez co wpisuje się w gnostycką tradycję poszukiwania wewnętrznego objawienia (oświecenia), dokonującego się poza światem religijnych instytucji. W upowszechnieniu się takiego „zwrotu w stronę subiektywizmu" kluczową rolę odegrał XIX-wieczny romantyzm i jego etyka autentyczności (Taylor 1996). Ostatnia część artykułu zostanie poświęcona kwestii istnienia strukturalnego podobieństwa między minimalizmem a buddyzmem zen. Należy jeszcze raz podkreślić, że obecność zen w twórczości minimalistów nie zawsze ma charakter bezpośredniego nawiązywania do tej formy buddyzmu, jednak można bez watpienia stwierdzić, że między protagonistami minimalizmu i buddyzmem zen istnieje zasadnicza zbieżność, ponieważ w obu tych przypadkach chodzi de facto o to samo: o eliminowanie rzeczy zbędnych, co ma pozwolić na dotarcie do tego, co istotne.

Leo Babauta w książce The Power of Less pisze o dwóch kluczowych zasadach prowadzących do uproszczenia życia: 1) ustalaniu granic, 2) dążeniu do znalezienia esencji, co pozwala na oszczędzanie energii oraz czasu (2009: 5-6). Zasady te - pisze dalej - stanowią zarazem istotę haiku, czyli krótkiego, 17-sylabowego, złożonego z trzech wersów utworu poetyckiego, charakterystycznego dla kultury Japonii. Babauta dostrzega w haiku to, co jest sednem minimalizmu: docieranie do istoty (essential), wydobywanie tego, co ważne, za sprawą radykalnego uproszczenia życia, odrzucenia tego, co zbędne czy mniej istotne. Z kolei Dominique Loreau w książce Sz̨tuka planowania dostrzega podobieństwa między czynnością sporządzania list a zasadami zen, które zalecaja pozbywanie się tego, co zbędne, aby móc się całkowicie oddać przeżywaniu życia i delektowaniu się nim (2011: 24). Francuska minimalistka dostrzega tutaj paralelę między sporządzaniem list a tworzeniem haiku. „Układanie list może nawet stać się sztuką, podobnie jak haiku" (tamże: 25). Zachodnia cywilizacja - pisze Loreau - choruje na nadmiar nic nieznaczących i pozbawionych głębi słów. Haiku - dodaje przypomina zen, jest stanem bliskim bezsłowia, w którym nazywa się coś, nie używając nazw. Haiku pozwala więc nakierować umysł na to, co istotne, 
podobnie listy, które - zdaniem Loreau - pozwalają uchwycić istotę rzeczy, wyeliminować to, co zbędne, dotrzeć do sedna sprawy. Co charakterystyczne, niemalże takiego samego wyrażenia („sedno sprawy”) używa w kontekście charakterystyki buddyzmu zen Daisetz T. Suzuki, najważniejszy bodaj popularyzator buddyzmu zen w USA (1979: 38).

Haiku i zen łączy nie tylko to, że są tak mocno związane z kultura Japonii, przenika je, by się tak wyrazić, ta sama duchowość, związana z poszukiwaniem prostoty oraz wewnętrznego spokoju. Chodzi tutaj także o „oświecenie”. Mariusz Rucki cytuje Reginalda H. Blytha, dostrzegającego w haiku „wyrażenie przejściowego oświecenia” (2012: 193), z kolei Alan W. Watts pisał, że zen można po prostu określić mianem „drogi momentalnego przebudzenia" (the way of instantaneous awakening) (1957: 218) ${ }^{8}$. Jak zauważał Watts, doświadczenie takiej chwilowości (momentariness) jest charakterystyczne dla malarstwa sumi, haiku czy sztuki walki mieczem kendo. Opisy takiego doświadczenia znajdziemy też w twórczości Babauty, który podobnie jak mistrzowie buddyzmu zen sugeruje, by skupiać swoją uwagę na „teraz” (2008: 30, 2009: 30). Babauta radzi: kiedy jesz, jedz, nie czytaj jedząc ani nie wykonuj innych czynności (np. nie prasuj), gdy zmywasz naczynia, zmywaj tylko naczynia, gdy bierzesz prysznic, skupiaj się tylko na tej czynności, nie rozpraszaj się. Rady, by się nie spieszyć, by czerpać przyjemność z codziennych czynności, by ćwiczyć, biegać, praktykować medytację, skupiać się na oddechu, choć nie sugerują żadnej konkretnej religii, przesycone są duchowością wewnętrznego spokoju, a zarazem zbiegaja z tym, co pochodzacy z Wietnamu mistrz zen, Thich Nhat Hanh, określa mianem cudu uważności. Gdy pisze: „Podczas zmywania naczyń powinniśmy być tylko zmywaniem naczyń [...]”, wskazuje na dwa sposoby zmywania: po to, by umyć naczynia (przyszłość), oraz by je zmywać, zmywanie dla zmywania (teraźniejszość) (1992: 12-13). Uważność, jak pisał Jon Kabat-Zinn, jest więc sztuką skupienia się na chwili, „stanem świadomości polegającym na niespiesznej, neutralnej uwadze skupionej na jednej rzeczy w pewnym czasie" (1994: 4, cyt. za Burch 2012: 2).

\footnotetext{
8 W polskim przekładzie książki Wattsa wyrażenie to zostało przetłumaczone właśnie jako „momentalne przebudzenie” (Watts 1997: 239). Rucki oddaje je jako „przejściowe oświecenie”, a z kolei w polskim przekładzie książki Suzukiego Zen i kultura japońska pojawia się wyrażenie „nagłe oświecenie” (Suzuki 2009: 32). Problem polega więc na przełożeniu przymiotnika instantaneous, który można oddać bądź jako „natychmiastowy”, bądź „chwilowy”.
} 
Minimalizm można potraktować jako wyraz sprzeciwu wobec konsumpcjonistycznej kultury, daleko mu jednak do siły kontestacji, którą niosła za sobą młodzieżowa kontrkultura z lat 60. i 70. ubiegłego wieku. A jednak nie należy wahać się przed potraktowaniem minimalizmu jako formy kontynuacji tej najsłynniejszej kontrkultury, zarazem jednak pamiętając, że i ona sama stanowiła kontynuację wcześniejszych tendencji kontrkulturowych, którym z jednej strony ton nadawała potrzeba romantyczna, przybierająca formę zwrotu w stronę prostoty, a z drugiej - nakierowanie ku własnemu wnętrzu, przejawiające się w poszukiwaniach duchowych i kwestionowaniu religijnych instytucji oraz autorytetów. Te same pragnienia odnajdujemy i w młodzieżowej kontestacji, i w minimalizmie. Duchowość ma zatem i swoje społeczne konsekwencje, skoro nawet najbardziej, wydawałoby się, indywidualne praktyki nie pozostaja bez wpływu na rzeczywistość społeczna. Jeśli chodzi o minimalizm i realizowaną na jego gruncie (oczywiście nie przez wszystkich minimalistów) duchowość wewnętrznego spokoju, związaną z duchową praktyką ascezy, to można tutaj dostrzec rozmaite inspiracje: buddyzm (nie tylko zen), feng shui, ale i chrześcijaństwo. W artykule szczególny akcent został położony na buddyzm (zwłaszcza buddyzm zen) z jeszcze jednego powodu: praktykowanie współczucia, życzliwości, tolerancji, wielkoduszności, nadziei Dalajlama określa mianem „elementarnej duchowości” (Dalajlama, Cutler 1998: 258) ${ }^{9}$. Do takiego typu duchowości odwołuje się także Leo Babauta, w niektórych fragmentach powołując się zresztą na Dalajlamę. W swojej książce Zen Habits Handbook for Life, w rozdziale poświęconym praktykowaniu współczucia, Babauta czterokrotnie cytuje Dalajlamę, między innymi tę jego myśl, w której twierdzi, że praktykowanie współczucia czyni szczęśliwszymi innych ludzi, ale i jednocześnie tego, kto praktykuje współczucie. Leo Babauta przytacza także cytat, w którym Dalajlama zachęca do praktykowania współczucia, miłości oraz życzliwości (Babauta 2008: 67). Autor Zen Habits formułuje „złotą zasadę”, która uczyni szczęśliwszym osobę ja praktykująca, a jednocześnie społeczność, w której ona żyje, uczyni lepsza. Na zasadę tę składać się mają następujące elementy: praktykowanie empatii i współczucia, okazywanie przyjacielskości i pomocność, słuchanie innych, odrzucanie stereotypów, porzucenie krytykowania oraz kontrolowania innych, upodobnianie się do dziecka, zaniechanie odwetu (Babauta 2008: 77-78). Czy podobne postulaty nie były także głoszone przez żyjących w czasach kontrkultury hipisów?

9 W polskim przekładzie pojawia się wyrażenie „duchowość podstawowa” (Dalajlama, Cutler 2000: 238). 
Bibliografia:

/// Babauta L. 2008. Zen Habits Handbook for Life. Hundreds of Tips for Simplicity, Happiness, Productivity, Waking Lion Press, West Valley City.

/// Babauta L. 2009. The Power of Less. The Fine Art of Limiting Yourself to the Essential... in Business and in Life, Hyperion, New York.

/// Babauta L. 2011. Zen To Done. The Ultimate Simple Productivity System, Waking Lion Press, West Valley City.

/// Becker J. 2013a. What is Minimalism. http://www.becomingminimalist.com/what-is-minimalism/; dostęp: 1.07.2014.

/// Becker J. 2013b. On living countercultural Lives. http://www.becomingminimalist.com/on-living-countercultural-lives/; dostęp: 10.10.2013.

/// Bruce S. 2000. The New Age and Secularisation, [w:] Beyond New Age. Exploring Alternative Spirituality, red. S. Sutcliffe, M. Bowman, Edinburgh University Press, Edinburgh, s. 220-236.

/// Bruce S. 2006. Secularization and the Impotence of Individualized Religion, „Hedgehog Review” 2006, nr 1-2(8), s. 35-45.

/// Burch M. A. 2012. Mindfulness. The Doorway to Simple Living, Simplicity Institute. http://simplicityinstitute.org/wp-content/uploads/2011/04/ MindfulnessSimplicityInstitute.pdf; dostęp: 1.07.2014.

/// Campbell C. 1972. The Cult, the Cultic Milieu and Secularization, „A Sociological Yearbook of Religion in Britain” 1972, nr 5, s. 119-136.

/// Campbell C. 2005. The Romantic Ethic and the Spirit of Modern Consumerism, Alcuin Academics, York.

/// Cusack C. M. 2013. The Western Reception of Buddhism. Celebrity and Popular Cultural Media as Agents of Familiarisation. https://www.equinoxpub.com/journals/index.php/ARSR/article/downloadSuppFile/10989/ $2257+\& \mathrm{~cd}=1 \& \mathrm{hl}=\mathrm{pl} \& \mathrm{ct}=\mathrm{clnk} \& \mathrm{gl}=\mathrm{pl} ;$ dostęp: 18.10.2013.

/// Dalajlama, Howard C. C. 1998. Art of Happiness. A Handbook For Living, Hodder \& Stoughton, London.

/// Dalajlama, Howard C. C. 2000. Sztuka szczésicia. Poradnik sycia, tlum. J. Grabiak, Dom Wydawniczy Rebis, Poznań.

/// D’Onza C. M. 2005. Buddyzm, tłum. K. Stopa, Wydawnictwo WAM, Kraków. 
/// Etzioni A. 2004. The Post Affluent Society, „Review of Social Economy” 2004, nr 3, vol. LXII, s. 407-420.

/// Giordan G. 2009. The Body between Religion and Spirituality, „Social Compass" 2009, nr 2(56), s. 226-236.

/// Grigsby M. 2004. Buying Time and Getting By. The Voluntary Simplicity Movement, State University of New York Press, Albany, NY.

/// Harnden Ph. 2003. Journeys of Simplicity. Traveling Light with Thomas Merton, Bashō, Edward Abbey, Annie Dillard \& Others, SkyLight Paths Publishing, Woodstock, Vermont.

/// Heelas P., Woodhead L., Seel B., Szerszynski B. i Tusting K. 2007. The Spiritual Revolution. Why Religion Is Giving Way to Spirituality, Blackwell Publishing, Oxford.

/// Inglehart R., Welzel Ch. 2007. Modernization, Cultural Change, and Democracy. The Human Development Sequence, Cambridge University Press, Cambridge.

/// Janion M., Żmigrodzka M. 2004. Romantyzm i egaystencja. Fragmenty niedokończonego drieła, Słowo/Obraz Terytoria, Gdańsk.

/// Jawłowska A. 1975. Drogi kontrkultury, Państwowy Instytut Wydawniczy, Warszawa.

/// Jeżowski M. 2010. Duchowość - paradygmat socjologii religii cミy socjologii moralności? A moze socjologia duchowości?, [w:] Religijność i duchowość - dawne $i$ nowe formy, red. M. Libiszowska-Żółtkowska, S. Grotowska, Zakład Wydawniczy „NOMOS”, Kraków, s. 66-78.

/// Kabat-Zinn J. 1994. Wherever You Are, There You Are. Mindfulness Meditation in Everyday Life, Hyperion, New York.

// / Kasperek A. 2012. Wolność spod znaku undergroundu. Duchowość (po)nowoczesna w perspektywie hermenentyki kultury i socjologii religii, Zakład Wydawniczy „NOMOS”, Uniwersytet Śląski, Kraków.

/// Kasperek A. 2013. Ocayszczajac drzwi percepcji. Szkic o idei imaginacji w romantyzmie, kontrkulturze $i$ New Age, "Studia Humanistyczne AGH” 2013, nr 3, s. 31-48.

/// Loreau D. 2008. Sztuka prostoty, tłum. J. Sobotnik, Jacek Santorski \& Co Agencja Wydawnicza, Warszawa.

/// Loreau D. 2011. Sztuka planowania, tłum. A. Waśko-Bongiraud, Wydawnictwo Czarna Owca, Warszawa. 
/// Luckmann Th. 1996. Niewidzialna religia. Problem religii we wspótczesnym społeczeństwie, tłum. L. Bluszcz, Zakład Wydawniczy „NOMOS”, Kraków. /// Meyer P. 1973. Historia sztuki europejskiej. Tom II: Od renesansu po czasy wspótczesne, Wydawnictwo Naukowe PWN, Warszawa.

/// Millburn J. F., Nicodemus R. 2011. Minimalism. Essential Essays, Asymmetrical Press, Columbia, Missouri.

/// Mouzelis N. 2012. Modernity. Religious Trends, [w:] Universal Rights in a World of Diversity. The Case of Religious Freedom, red. M. A. Glendon, H. F. Zacher, „Pontifical Academy of Social Sciences” Acta 17, Vatican City, s. 71-90. www.pass.va/content/dam/scienzesociali/pdf/acta17/ acta17-mouzelis.pdf; dostęp: 1.07.2014.

/// Nhat Hanh Th. 1992. Cud uważności. Zen w sætuce codziennego ṡycia. Prosty podrecznik medytacji, tłum. G. Draheim, Jacek Santorski \& CO Agencja Wydawnicza, Warszawa.

/// Possamai A. 2005. Religion and Popular Culture. A Hyper-Real Testament, P.I.E., Peter Lang, Oxford.

/// Roszak Th. 1973. The Making of a Counter Culture. Reflections on the Technocratic Society \& Its Youthful Oppositions, Faber and Faber, London.

/// Rucki M. 2012. Daisetz. Teitaro Suzuki (1870-1966) i jego anglojezyczna prezentacja zenu, Wydawnictwa Uniwersytetu Warszawskiego, Warszawa.

/// Quispel G. 2008. Gnosis and Culture, [w:] Gnostica, Judaica, Catholica. Collected Essays of Gilles Quispel, red. J. van Oort, Brill, Leiden, s. 141-153.

/// Strobel T. 2012. You Can Buy Happiness (and It's Cheap). How One Woman Radically Simplified Her Life and How You Can Too, New World Library, Novato, California.

/// Suzuki D. T. 1979. Wprowadzenie do buddyzmu Zen, tłum. M. Grabowska, A. Grabowski, Czytelnik, Warszawa.

/// Suzuki D. T. 2009. Zen i kultura japońska, tłum. B. Szymańska, P. Mróz, A. Zalewska, Wydawnictwo Uniwersytetu Jagiellońskiego, Kraków.

/// Taylor Ch. 1991. The Ethics of Authenticity, Harvard University Press, Cambridge.

/// Taylor Ch. 1996. Etykea autentyczności, tłum. A. Pawelec, Społeczny Instytut Wydawniczy Znak, Fundacja im. Stefana Batorego, Kraków, Warszawa. 
/// Taylor Ch. 2007. A Secular Age, The Belknap Press of Harvard University Press, Cambridge, Massachusetts, London.

/// Watts A. W. 1957. The Way of Zen, Penguin Books, New York.

/// Watts A. W. 1997. Droga zen, tłum. S. Musielak, Dom Wydawniczy Rebis, Poznań.

// / Wilson K. 2012. Becoming a Minimalist. Your Guide to Living a Great Life with Less Through Minimalism [Kindle Edition].

/// York M. 2001. New Age Commodification and Appropriation of Spirituality, „Journal of Contemporary Religion” 2001, nr 3, vol. 16, s. 361-372.

\section{/// Abstrakt}

Z perspektywy historii Zachodu kontrkulturowy ruch hipisowski można potraktować jako kolejną ekspresję pojawiającej się co pewien czas tendencji kulturowej, w której odradza się pragnienie uwolnienia od posiadania rzeczy, zakwestionowanie wartości charakterystycznych dla społeczeństwa wysokiej konsumpcji, powrót do ideału życia prostego. Celem artykułu jest analiza współczesnego zjawiska, określanego mianem minimalizmu, w wielu punktach nawiązującego do kontrkulturowych postulatów, choć niebędącego prostą kontynuacją hipisowskiej kontestacji. Zjawisko to, dla którego opisu najbardziej adekwatnym terminem wydaje się termin „styl życia”, wiąże się przede wszystkim z blogosfera, a do najbardziej popularnych minimalistów należą: Leo Babauta, Joshua Becker, Joshua Fields Millburn czy Ryan Nicodemus. Choć minimalizm jest postrzegany przede wszystkim jako styl życia, w którym ludzie starają się uwolnić od nadmiaru rzeczy, w artykule zjawisko to zostanie potraktowane jako forma antykonsumpcjonistycznej duchowości, której źródeł należy poszukiwać w zachodniej (głównie w USA) fascynacji buddyzmem zen. W artykule zostanie podjęta także próba pokazania istnienia strukturalnych podobieństw między minimalizmem i buddyzmem zen.

Słowa kluczowe:

minimalizm, antykonsumpcjonizm, dobrowolna prostota, kontrkultura, duchowość, buddyzm zen

\section{/// Abstract}

From the standpoint of the history of the West, the countercultural hippie movement can be treated as another manifestation of a certain 
recurring cultural tendency in which the wish to break free from possessions is reborn, as well as questioning the values of high consumerism society and a return to the ideal of simple life. The article aims at the analysis of the contemporary phenomenon called minimalism, which in many points refers to countercultural postulates despite not being a simple continuation of the hippie contestation. This phenomenon can be most adequately referred to as "lifestyle" and is mostly associated with the blogosphere. The most popular minimalists are: Leo Babauta, Joshua Becker, Joshua Fields Millburn, and Ryan Nicodemus. Although minimalism is perceived mainly as a lifestyle in which people tend to free from the excess of things, in this article it will be treated as a form of anti-consumerist spirituality whose sources should be traced back in the western (taking place mostly in the US) fascination with Buddhism Zen. What will be also attempted in this study is showing the existence of structural similarities between minimalism and Buddhism Zen.

Keywords:

minimalism, anti-consumerism, voluntary simplicity, counterculture, spirituality, Buddhism Zen 